\title{
Sequence variation in the ATP8B1 gene and intrahepatic cholestasis of pregnancy
}

\author{
Jodie N Painter*,1,2, Miia Savander ${ }^{1,2}$, Anne Ropponen ${ }^{3}$, Nina Nupponen ${ }^{4}$, Seija Riikonen ${ }^{4}$, \\ Olavi Ylikorkala ${ }^{4}$, Anna-Elina Lehesjoki ${ }^{1,2}$ and Kristiina Aittomäki ${ }^{1,5}$
}

\begin{abstract}
${ }^{1}$ Folkhälsan Institute of Genetics, Biomedicum Helsinki, University of Helsinki, Helsinki, Finland; ${ }^{2}$ Department of Medical Genetics, Biomedicum Helsinki, University of Helsinki, Helsinki, Finland; ${ }^{3}$ Department of Gynaecology and Obstetrics, Helsinki University Central Hospital, Helsinki, Finland; ${ }^{4}$ Department of Oncology, Biomedicum Helsinki, University of Helsinki, Helsinki, Finland; ${ }^{5}$ Department of Clinical Genetics, Helsinki University Central Hospital, Helsinki, Finland
\end{abstract}

Intrahepatic cholestasis of pregnancy (ICP) is a cholestatic condition that may affect women during the third trimester of pregnancy. Symptoms experienced by these women generally resolve spontaneously following delivery, but prior to delivery the fetus is at increased risk of intrauterine distress and sudden intrauterine death. The genetic etiology of most cases of ICP is unknown, although heterozygous carriers of mutations causing progressive familial intrahepatic cholestasis (PFIC) diseases may experience ICP. When examining linkage to known cholestasis genes, affected members of four Finnish ICP families shared haplotypes around ATP8B1, the gene responsible for PFIC1. This gene was subsequently screened in 176 familial and sporadic ICP patients. A total of 17 sequence changes were detected, five exonic and 12 intronic. No intronic change was associated with ICP in sporadic cases. Four intronic changes segregated with ICP in three families, a different change in each of two families and three changes in another family, although the significance of this is currently unknown. Three exonic changes were nonsynonymous, one (in exon 23 ) is probably a polymorphism while two predict novel amino-acid replacements (N45T and K203R). These changes, in exons 2 and 7, were detected in one individual each, and may have predisposed these individuals to ICP. In conclusion, although the exon 2 and 7 changes may have functioned as risk alleles, ATP8B1 is probably not a major gene contributing to the occurrence of ICP. European Journal of Human Genetics (2005) 13, 435-439. doi:10.1038/sj.ejhg.5201355

Published online 12 January 2005

Keywords: ATP8B1; DHPLC; obstetric cholestasis

\section{Introduction}

Intrahepatic cholestasis of pregnancy (ICP) is a cholestatic condition complicating otherwise normal pregnancies. ICP usually arises in affected women during the third trimester and is characterized by generalized and possibly intense itching and increased levels of total bile acids and

*Correspondence: Dr J Painter, Folkhälsan Institute of Genetics, Biomedicum Helsinki, PO Box 63, University of Helsinki 00014, Haartmaninkatu 8, Helsinki, Finland. Tel.: + 3589191 25068; Fax: + 3589191 25073; E-mail: jodie.painter@helsinki.fi

Received 13 July 2004; revised 8 November 2004; accepted 11 November 2004 transaminases in maternal serum. While this condition can be particularly uncomfortable for the mother, the prognosis is generally good, as symptoms resolve spontaneously soon after delivery and leave no permanent liver damage. The outcome for the fetus is less certain, as ICP is associated with increased rates of premature birth, intrauterine distress and also sudden intrauterine death. ${ }^{1,2}$ In Scandinavian countries, ICP occurs in $0.5-1.5 \%$ of pregnancies. $^{3,4}$

The genetic etiology of ICP is largely unknown, and likely to be heterogenous. Currently, investigation of the genetic background of ICP is focused mainly on candidate 

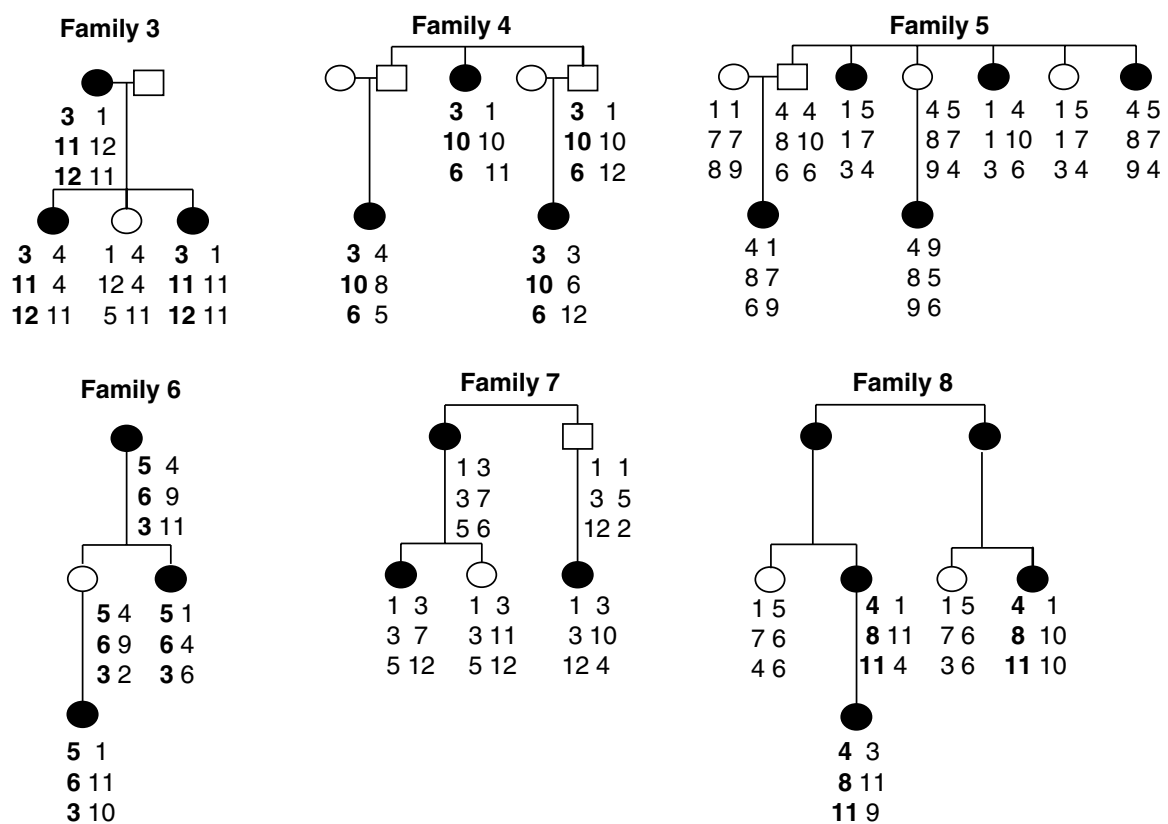

Figure 1 Genotypes for microsatellites D18S977, D18S849 and D18S1144 flanking the ATP8B1 gene for six Finnish ICP families. Shared haplotypes are in bold. Pedigrees and microsatellite genotypes for Families 1 and 2 are detailed in Savander et al. $^{3}$

genes, particularly those causing cholestatic diseases. Mutations in three genes, ATP8B1, ABCB11 and ABCB4, cause the recessively inherited progressive familial intrahepatic cholestasis (PFIC) types 1, 2 and 3. Heterozygous mothers of children with PFIC3 may experience ICP. ${ }^{5-7}$ Subsequent screening has revealed, however, that mutations in $A B C B 4$ are responsible for ICP in only a minority of women, ${ }^{8,9}$ and the importance of $A B C B 11$ is yet to be determined. ${ }^{9-11}$

In a previous study, Savander $\mathrm{et} \mathrm{al}^{3}$ found no evidence for linkage to $A T P 8 B 1, A B C B 4$ or $A B C B 11$ in two Finnish ICP families. Mutations in $A T P 8 B 1$ cause two distinct diseases, PFIC1 and benign recurrent intrahepatic cholestasis (BRIC). ${ }^{12}$ Early reports suggested that PFIC1 and BRIC carriers may experience ICP. ${ }^{13,14}$ PFIC1 manifests as cholestasis in infancy and progresses to end-stage liver disease before early adulthood. In contrast, BRIC may manifest at any age, occurs episodically, and resolves spontaneously leaving no permanent liver damage, thus resembling ICP. The aim of this study was to investigate the possible association between $A T P 8 B 1$ and ICP, by testing six additional families for linkage to ATP8B1 and screening a large cohort of familial and sporadic ICP patients for ATP8B1 sequence variation.

\section{Materials and methods}

We screened 176 Finnish ICP patients, 34 affected women from eight ICP families and 142 sporadic patients who experienced ICP but had no significant family history. All women fulfilled the study criteria for ICP (serum aspartate aminotransferase $>35 \mathrm{U} / \mathrm{l}$, serum alanine aminotransferase $>35 \mathrm{U} / \mathrm{l}$ and/or serum bile acid values $>8 \mu \mathrm{mol} / \mathrm{l}$ with or without itching and negative for hepatitis $\mathrm{B}$ and $\mathrm{C}$ ). Control groups (50 females, 50 males) were comprised of samples from 100 healthy Finnish blood donors, and of $100 \mathrm{CEPH}$ samples chosen randomly from among those listed as grandparents. The study was approved by the institutional ethics committee and informed consent was obtained from all individuals.

Members of the six additional ICP families were genotyped at three microsatellite loci (D18S977, D18S849 and D18S1144) flanking ATP8B1 (Figure 1). LOD scores were calculated with Genehunter version 2.1. Members of all eight ICP families and all sporadic cases were screened for variation in ATP8B1 by denaturing high-performance liquid chromatography (dHPLC) (either an Agilent 1100 Series, Agilent Technologies, or a 3500HT WAVE, Transgenomic). Primer sequences and dHPLC conditions are in Table 1. Each exon was sequenced for all affected members of the eight ICP families, all samples exhibiting variant dHPLC traces and eight randomly chosen homozygote samples.

The location and description of the genomic changes are in reference to NM_005603. Coding exons are numbered $2-28$, as an additional $5^{\prime}$ untranslated exon was recently discovered. ${ }^{15}$ Differences in the proportion of heterozygotes between the sporadic ICP samples and both Finnish and CEPH controls were analyzed with two-tailed $t$ tests, 
Table 1 Primer sequences, PCR annealing temperatures and dHPLC analysis temperatures for the 27 coding exons of ATP8B1

\begin{tabular}{|c|c|c|c|c|}
\hline Exon & Primer sequences & Size (bp) & PCR annealing temp & dHPLC conditions \\
\hline 2 & $\begin{array}{l}\text { F TGCAGGCAGTATTCAACCAA } \\
\text { R CACGCAAAATAGACCGATCA }\end{array}$ & 367 & $\mathrm{TD} 60-50^{\circ} \mathrm{C}$ & $\mathrm{T} 58.3^{\circ} \mathrm{C}$ \\
\hline 3 & $\begin{array}{l}\text { F CTGCAATGAGCAGTTTCCAA } \\
\text { R GTTACGTGGAAGGCAGGTGT }\end{array}$ & 341 & $\mathrm{TD} 60-50^{\circ} \mathrm{C}$ & $\mathrm{T} 56.7^{\circ} \mathrm{C}$ \\
\hline 4 & $\begin{array}{l}\text { F TGTAAGCTGTGGGACTTGTGA } \\
\text { R TAGGCTGGTTCTGTGTATGAGG }\end{array}$ & 275 & $\mathrm{TD} 55-45^{\circ} \mathrm{C}$ & T $55.6^{\circ} \mathrm{C}$ \\
\hline 5 and 6 & $\begin{array}{l}\text { F TGACGGTGATGAGACTTGG } \\
\text { R GGCGACAGAGCGAGACTCTA }\end{array}$ & 527 & $\mathrm{TD} 60-50^{\circ} \mathrm{C}$ & $\mathrm{T} 55.4^{\circ} \mathrm{C}$ \\
\hline 7 and 8 & $\begin{array}{l}\text { F TCCСTTGCСTGTAACTTAAAATG } \\
\text { R TTTAAATCAGGCCCATCGAG }\end{array}$ & 261 & $\mathrm{TD} 55-45^{\circ} \mathrm{C}$ & A $57^{\circ} \mathrm{C}$ \\
\hline 9 and 10 & $\begin{array}{l}\text { F GGCTTCATGTCCAGGTATGG } \\
\text { R TGGTIITGATGGACAAAGGA }\end{array}$ & 553 & TD $55-45^{\circ} \mathrm{C}$ & A $56^{\circ} \mathrm{C}$ \\
\hline 11 & $\begin{array}{l}\text { F ATGCCTGGCCAAGAAGAGTA } \\
\text { R CCCTTCTTCCTGCATTTGAA }\end{array}$ & 326 & $\mathrm{TD} 55-45^{\circ} \mathrm{C}$ & A $55^{\circ} \mathrm{C}$ \\
\hline 12 & $\begin{array}{l}\text { F GGAAATGCAAGAGGTTGGAA } \\
\text { R GGCACTATGTTGGGAGAAGG }\end{array}$ & 319 & $\mathrm{TD} 60-50^{\circ} \mathrm{C}$ & $\mathrm{T} 57.9^{\circ} \mathrm{C}$ \\
\hline 13 & $\begin{array}{l}\text { F TCCGAGCTCTCTACGGAAAA } \\
\text { R AAATGAGTGACGGCTTCCAC }\end{array}$ & 272 & $50^{\circ} \mathrm{C}$ & A $59^{\circ} \mathrm{C}$ \\
\hline 14 & $\begin{array}{l}\text { F AAGCAAAGCCAGGTAAGGAG } \\
\text { R CAGCATCCCAAACGATTCTT }\end{array}$ & 155 & $\mathrm{TD} 60-50^{\circ} \mathrm{C}$ & $\mathrm{T} 58^{\circ} \mathrm{C}$ \\
\hline 15 & $\begin{array}{l}\text { F TGAAACCTTGCCTTTGAAGAA } \\
\text { R GCCTGAGATGCCAGAGAAAC }\end{array}$ & 274 & TD $60-50^{\circ} \mathrm{C}$ & A $54^{\circ} \mathrm{C}$ \\
\hline 16 & $\begin{array}{l}\text { F GGGATTTCTCTCGCTTCCTT } \\
\text { R TGGGCACAAGCAACATCTAA }\end{array}$ & 271 & $54^{\circ} \mathrm{C}$ & $\mathrm{A} 61^{\circ} \mathrm{C}$ \\
\hline 17 & $\begin{array}{l}\text { F CCGATACTGAACTGCTGCAC } \\
\text { R TCAGAATCCCTTGCAGAAAGA }\end{array}$ & 264 & $\mathrm{TD} 55-45^{\circ} \mathrm{C}$ & $\mathrm{T} 56.3^{\circ} \mathrm{C}$ \\
\hline 18 & $\begin{array}{l}\text { F TTCTTTGCATTGGTGGATTT } \\
\text { R CCTTCTTCCATTGTGCCAGT }\end{array}$ & 343 & $50^{\circ} \mathrm{C}$ & A $54^{\circ} \mathrm{C}$ \\
\hline 19 & $\begin{array}{l}\text { F GAGAGCAGCAACCAGGATG } \\
\text { R TCATCTTGGGCAAAGGAAAC }\end{array}$ & 308 & $52^{\circ} \mathrm{C}$ & A $55^{\circ} \mathrm{C}$ \\
\hline 20 & $\begin{array}{l}\text { F TGAGATGGGCAGATCACTTG } \\
\text { R TTGCATTTGCAAAGATGAGC }\end{array}$ & 299 & $51^{\circ} \mathrm{C}$ & A $55^{\circ} \mathrm{C}$ \\
\hline 21 & $\begin{array}{l}\text { F TCTCAGAGTCAAGGGCCTATTT } \\
\text { R GCATCTAAAAGTGGCTCCAAA }\end{array}$ & 267 & TD $55-45^{\circ} \mathrm{C}$ & $\mathrm{T} 58.2^{\circ} \mathrm{C}$ \\
\hline 22 & $\begin{array}{l}\text { F TCTTGGGAATGGTACTCCTG } \\
\text { R CCCTACACATTCCAGCCATT }\end{array}$ & 425 & $55^{\circ} \mathrm{C}$ & A $56^{\circ} \mathrm{C}$ \\
\hline 23 & $\begin{array}{l}\text { F GGATGGTGAGCAAGAGCTTC } \\
\text { R TAAGGAGACACAGCCCCAAA }\end{array}$ & 497 & $54^{\circ} \mathrm{C}$ & $\begin{array}{l}\text { A } 57^{\circ} \mathrm{C}(\mathrm{I})^{\mathrm{a}} \\
\text { A } 59^{\circ} \mathrm{C}(\mathrm{E})\end{array}$ \\
\hline 24 & $\begin{array}{l}\text { F CATAGCAAGACCCCCATCTC } \\
\text { R CCTTGATGCCTGACAACAGA }\end{array}$ & 361 & $51^{\circ} \mathrm{C}$ & T $58^{\circ} \mathrm{C}$ \\
\hline 25 & $\begin{array}{l}\text { F CAGGCTGCAACTTTTGTGA } \\
\text { R CACTGAATACGGCCAATGAA }\end{array}$ & 370 & $\mathrm{TD} 55-45^{\circ} \mathrm{C}$ & A $59^{\circ} \mathrm{C}$ \\
\hline 26 & $\begin{array}{l}\text { F TCAAGCCACATCATGCCTAA } \\
\text { R CCAGCCATTCCACCTTGTAT }\end{array}$ & 353 & TD $55-45^{\circ} \mathrm{C}$ & $\mathrm{T} 54.5^{\circ} \mathrm{C}$ \\
\hline 27 & $\begin{array}{l}\text { F GGACTACAGGTGCACAC } \\
\text { R AATTTTGCAGGAAACGTGCT }\end{array}$ & 441 & $53^{\circ} \mathrm{C}$ & $\mathrm{T} 58.5^{\circ} \mathrm{C}$ \\
\hline 28 & $\begin{array}{l}\text { F GACAGAACTGCCTGCATCAA } \\
\text { r TCCAACCCAAGGAGTTTGTT }\end{array}$ & 540 & TD $50-45^{\circ} \mathrm{C}$ & $\mathrm{T} 60.2^{\circ} \mathrm{C}$ \\
\hline
\end{tabular}

A indicates exons analysed using the Agilent 1100 series, and T those run using the Transgenomic WAVE ${ }^{\mathbb{R}}$.

${ }^{a}$ Different temperatures were needed to produce heteroduplex peaks for the exon 23 intronic (I) and exonic (E) SNPS.

where $P \leq 0.01$ was taken to indicate a significant difference. The potential impact of amino-acid changes were assessed with the SIFT program, ${ }^{16}$ which predicts tolerated and nontolerated amino-acid substitutions based on comparison to similar sequences.

\section{Results}

When all eight families were included in the linkage analysis, single-point LOD scores were -1.99 for D18S977,
0.07 for D18S849 and -0.48 for D18S1144. Haplotypes were, however, shared by affected members in families 3,4 , 6 and 8 (Figure 1). When linkage was calculated for these families, the LOD scores were 2.00 for D18S977, 2.18 for D18S849 and 2.79 for D18S1144. Additional markers, haplotypes and linkage results are available from the authors.

Exonic base changes were detected in five exons (Table 2). One sporadic patient had a heterozygous c.134A >C change in exon 2, predicting the replacement of asparagine 
Table 2 ATP8B1 sequence variants in Finnish ICP patients

\begin{tabular}{|c|c|c|c|c|c|c|}
\hline Exon & $\begin{array}{c}\text { DNA variation } \\
\text { (inferred amino-acid change) }\end{array}$ & $\begin{array}{l}\text { Heterozygous } \\
\text { ICP patients }\end{array}$ & $\begin{array}{c}\% I C P \\
(n=142)\end{array}$ & $\begin{array}{l}\% \text { Controls } \\
(n=100)\end{array}$ & $\begin{array}{l}\% \text { CEPH } \\
(n=100)\end{array}$ & SNP identifier ${ }^{\mathrm{a}}$ \\
\hline \multicolumn{7}{|l|}{ Exonic } \\
\hline 2 & c. $134 \mathrm{~A}>\mathrm{C} \quad(\mathrm{N} 45 \mathrm{~T})$ & $1 / 142$ & 0.7 & 0 & 0 & - \\
\hline 3 & c. $246 \mathrm{~A}>\mathrm{G}$ & $1 / 142$ & 0.7 & 0 & $\mathrm{~N} / \mathrm{A}$ & chr18:55158747 \\
\hline 7 & c. $607 \mathrm{~A}>\mathrm{G} \quad(\mathrm{K} 203 \mathrm{R})$ & $1 / 142$ & 0.7 & 0 & 0 & - \\
\hline 11 & c. $1014 \mathrm{C}>\mathrm{T}$ & $3 / 142$ & 2.1 & 0 & 0 & - \\
\hline 23 & c. $2855 \mathrm{G}>\mathrm{A} \quad(\mathrm{R} 952 \mathrm{Q})$ & $21 / 142$ & 14.7 & 14 & 28 & chr18:55107494 \\
\hline \multicolumn{7}{|c|}{ Intronic } \\
\hline 3 & c. $181-72 \mathrm{G}>\mathrm{A}$ & $22 / 142$ & 15.5 & 23 & 8 & - \\
\hline 6 & c. $554+122 \mathrm{C}>\mathrm{T}$ & $64 / 142$ & 45.1 & 58 & $\mathrm{~N} / \mathrm{A}$ & rs4940989 \\
\hline 11 & c. $1029+35 G>A$ & $6 / 142$ & 4.2 & 3 & N/A & SNP 51293 \\
\hline 17 & c.1819-39_41delAA & $58 / 142$ & 40.8 & 36 & 28 & - \\
\hline 20 & c. $2210-11 \overline{4} \mathrm{~T}>\mathrm{C}$ & $71 / 142$ & 50 & 40 & $\mathrm{~N} / \mathrm{A}$ & rs17846 \\
\hline 20 & c.2210-45_50dupATAAAA & 28/142 & 19.7 & 21 & 26 & chr18:55119433 \\
\hline 23 & c. $2932+59 \mathrm{~T}>\mathrm{A}$ & $63 / 142$ & 44.4 & 33 & 31 & chr18:55107359 \\
\hline 27 & c. $3401-175 C>T$ & $68 / 142$ & 47.9 & 42 & $\mathrm{~N} / \mathrm{A}$ & rs8097764 \\
\hline 27 & c. $3401-167 \mathrm{C}>\mathrm{T}$ & $54 / 142$ & $38: 0$ & 41 & $\mathrm{~N} / \mathrm{A}$ & rs167603 \\
\hline 27 & c. $3401-108 \mathrm{C}>\mathrm{T}$ & $64 / 142$ & 45.1 & 48 & 36 & - \\
\hline 27 & c. $3531+8 G>T$ & $37 / 142$ & 26.1 & 32 & 30 & chr18:55102583 \\
\hline 28 & c. $3532-15 \mathrm{C}>\mathrm{T}$ & $57 / 142$ & 40.1 & 41 & 37 & chr18:55100951 \\
\hline
\end{tabular}

Description of the genomic changes follows the current recommendations of the Human Genome Variation Society (http://www.genomic.unimelb.edu.au/mdi/mutnomen/). CEPH samples were not analyzed (N/A) for most SNPs described in the Entrez SNP database (NCBI).

${ }^{a}$ rs SNPs are detailed at http://www.ncbi.nlm.nih.gov/SNP/, SNP 51293 at http://www.mutationdiscovery.com and chr18: variants at http:// www.pharmgkb.org.

with threonine. Another sporadic patient was heterozygous for a c.607A $>\mathrm{G}$ change in exon 7, predicting the replacement of lysine by glutamic acid. No control sample $(n=200)$ carried either of these changes. Of the 142 sporadic patients, 21 were heterozygous for a known c. $2855 \mathrm{G}>\mathrm{A}$ change in exon 23, predicting the replacement of arginine by glutamine. Heterozygotes for this change were equally frequent among ICP patients and Finnish controls (14.7 and 14\% of samples), and twice as frequent among CEPH controls (28\%). SIFT analysis predicted that the amino-acid replacements would be tolerated for the exon 7 change but not for the exon 2 and 23 changes. Synonymous changes were found in one patient in exon 3 and in three patients in exon 11, neither of which were detected in controls. All Finnish samples were homozygous for the alternate allele of a known SNP in exon 27 (rs222581, homozygous A).

Heterozygote frequencies did not differ between the sporadic ICP samples and controls for any intronic change (Table 2). Four changes segregated with ICP in three families: in Family 4 c. $554+122 \mathrm{C}>\mathrm{T}$ adjacent to exon 6 , in Family 8 c.1819-39_41delAA adjacent to exon 17 and in Family 6 c.181-72G $>$ A adjacent to exon 3, c. $554+122 \mathrm{C}>\mathrm{T}$ and c.2210-114T $>\mathrm{C}$ adjacent to exon 20 .

\section{Discussion}

We detected five exonic base changes, three of which were novel, among 176 sporadic and familial ICP patients. Three changes would result in the replacement of an amino acid. In addition, there were 12 intronic changes, three novel, none of which was associated with sporadic ICP in our sample group. As dHPLC can detect heterozygotes with high specificity and sensitivity, it is unlikely that we have missed any common, major ATP8B1 mutations contributing to ICP.

Heterozygotes for the c.2855G $>$ A change in exon 23, in an area coding for part of the second cytoplasmic loop, were equally frequent among ICP patients and Finnish controls, and twice as frequent in CEPH controls. Although SIFT analysis predicted that replacement by glutamine would not be tolerated, it is probably a common sequence variant and therefore unlikely to contribute to ICP.

Base changes in exons 2 and 7 were each detected in one ICP patient. The c. $134 \mathrm{~A}>\mathrm{C}$ exon 2 change occurs in a region coding for the $\mathrm{N}$ terminus of the protein, extending into the cytoplasm. No similar sequences were returned in a BLAST search with this exon; hence, the SIFT analysis predicted that this replacement would not be tolerated. Replacement of an acidic residue (arginine) with a polar residue (threonine), while both are small amino acids, may have an affect in this position. The c.607A $>\mathrm{G}$ exon 7 change, in an area coding for the first cytoplasmic loop, would result in the replacement of lysine by glutamic acid, the residue present in this approximate position in two of the closest human homologues of ATP8B1, ATP8B2 and $A T P 8 B 4$. This replacement was, therefore, predicted to be tolerated. However, whether this change is a mutation or a polymorphism is unknown. 
Intronic changes occurred with approximately equal frequencies in sporadic patients and controls. However, four intronic changes segregated with ICP in three families, with three changes in one family (Family 6). The significance of this is hard to determine. One plausible explanation could be that these alleles are linked to mutations in the ATP8B1 promotor region, which remains to be identified. Mutations in this area may turn out to be important causes of cholestatic disease, particularly as the majority of both PFIC1 and BRIC patients do not have exonic mutations in ATP8B $1 .{ }^{15}$ Alternately, these changes could be linked to another, as yet unidentified, cholestasis gene.

PFIC and BRIC are recessively inherited diseases, while familial ICP appears to be dominantly inherited. ${ }^{5,17}$ That ICP can occur in women heterozygous for mutations in cholestasis genes supports the idea that mutations that cause a serious disease in homozygous form may function as risk alleles in heterozygous form, although it is presently unknown whether the changes detected in this study predispose to ICP.

Recently, a number of studies have suggested associations between genetic polymorphisms and ICP, which suggests that ICP may have a complex genetic background. Affected women experience cholestasis only when pregnant, and hence carry risk alleles that cause the disease only during this time of particular stress. Aside from mutations found in $A B C B 4$ in isolated individuals, the functional significance of most associations is unknown. Although our results indicate that ATP8B1, a putative ICP candidate gene, is not a major gene contributing to the occurrence of ICP in a large cohort of familial and sporadic Finnish ICP patients, the exon 2 and exon 7 changes may be risk alleles predisposing to ICP. Clearly, much further research is needed to determine the genetic etiology of this intriguing disease.

\section{Acknowledgements}

We thank the ICP patients for their cooperation. Sinikka Lindh, MarjaLeena Järvinen and Katja Kuosa for collecting the ICP samples and an anonymous reviewer for constructive comments on an earlier draft of the manuscript. This work was funded by the Sigrid Juselius Foundation and a Finnish state grant, TYH 2210.

\section{References}

1 Laatikainen T, Ikonen E: Fetal prognosis in obstetric hepatosis. Ann Chir Gynaecol 1975; 64: 155-165.

2 Laatikainen T, Tulenheimo A: Maternal serum bile acid levels and fetal distress in cholestasis of pregnancy. Int J Gynaecol Obstet 1984; 22: 91-94.

3 Savander M, Ropponen A, Avela K et al: Genetic evidence of heterogeneity in intrahepatic cholestasis of pregnancy. Gut 2003; 52: $1025-1029$.
4 Berg B, Helm G, Petersohn L, Tryding N: Cholestasis of pregnancy. Clinical and laboratory studies. Acta Obstet Gynecol Scand 1986; 65: 107-113.

5 Jacquemin E, Cresteil D, Manouvrier S, Boute O, Hadchouel M: Heterozygous non-sense mutation of the MDR3 gene in familial intrahepatic cholestasis of pregnancy. Lancet 1999; 353: 210-211.

6 Dixon PH, Weerasekera N, Linton KJ et al: Heterozygous MDR3 missense mutation associated with intrahepatic cholestasis of pregnancy: evidence for a defect in protein trafficking. Hum Mol Genet 2000; 9: 1209-1217.

7 Gendrot C, Bacq Y, Brechot M-C, Lansac J, Andres C: A second heterozygous MDR3 nonsense mutation associated with intrahepatic cholestasis of pregnancy. J Med Genet 2003; 40: e32, ( http://www.jmedgenet.cim/cgi/content/full/40/3/e32 ).

8 Müllenbach R, Linton KJ, Wiltshire $\mathrm{S}$ et al: ABCB4 gene sequence variation in women with intrahepatic cholestasis of pregnancy. J Med Genet 2003; 40: e70, ( http://www.jmedgenet.cim/cgi/ content/full/40/5/e70).

9 Pauli-Magnus C, Lang T, Meier Y et al: Sequence analysis of bile salt export pump (ABCB11) and multidrug resistance p-glycoprotein 3 (ABCB4, MDR3) in patients with intrahepatic cholestasis of pregnancy. Pharmacogenetics 2004; 14: 91-102.

10 Eloranta M-L, Häkli T, Hiltunen M, Helisalmi S, Punnonen K, Heinonen S: Association of single nucleotide polymorphisms of the bile salt export pump gene with intrahepatic cholestasis of pregnancy. Scand J Gastroenterol 2003; 38: 648-652.

11 Painter JN, Savander M, Sistonen P, Lehesjoki A-E, Aittomäki K: A known polymorphism in the bile salt export pump gene is not a risk allele for intrahepatic cholestasis of pregnancy. Scan $J$ Gastroenterol 2004; 39: 694-695.

12 Bull LN, van Eijk MJT, Pawlikowska L et al: A gene encoding a P-type ATPase mutated in two forms of heteditary cholestasis. Nat Genet 1998; 18: 219-223.

13 Clayton RJ, Iber FL, Ruebner BH, McKusick VA: Byler disease. Fatal familial intrahepatic cholestasis in an Amish kindred. Am J Dis Child 1969; 117: 112-124.

14 de Pagter AGF, van Berge Henegouwen GP, ten Bokkel Huinink JA, Brandt K-H: Familial benign recurrent intrahepatic cholestasis: interrelation with intrahepatic cholestasis of pregnancy and from oral contraceptives. Gastroenterology 1976; 71: 202-207.

15 Klomp LWJ, Vargas JC, van Mil SWC et al: Characterization of mutations in ATP8B1 associated with hereditary cholestasis. Hepatology 2004; 40: 27-38.

$16 \mathrm{Ng} \mathrm{PC}$, Henikoff S: Accounting for human polymorphisms predicted to affect protein function. Genome Res 2002; 12: 436-446.

17 Holzbach RT, Sivac DA, Braun WE: Familial recurrent intrahepatic cholestasis of pregnancy: a genetic study providing evidence for transmission of a sex-limited, dominant trait. Gastroenterology 1983; 85: 175-179.

18 Heiskanen JTM, Pirskanen MM, Hiltunen MJ, Mannermaa AJ, Punnonen KRA, Heinonen ST: Insertion-deletion polymorphism in the gene for angiotensin-converting enzyme is associated with obstetric cholestasis but not with preeclampsia. Am J Obstet Gynecol 2001; 185: 600-603.

19 Chen F, Fan L, Xu L, Yao F: Relationship between human leukocyte antigen-DRB1 allele gene polymorphism and intrahepatic cholestasis of pregnancy. Zhonghua Fu Chan Ke Za Zhi 2002; 37: 519-522, (In Chinese with English abstract).

20 Laasanen J, Hiltunen M, Romppanen E-L, Punnonen K, Mannermaa A, Heinonen S: Microsatellite marker association at chromosome region 2p13 in Finnish patients with preeclampsia and obstetric cholestasis suggests a common risk locus. Eur J Hum Genet 2003; 11: 232-236. 